\title{
The Study of the Didactic Values in the Folklore of the Origin of Boyolali Regency Name
}

\author{
Ira Prihapsari, Andayani, Sarwiji Suwandi \\ Department of Indonesian Language Education, Universitas Sebelas Maret, Indonesia
}

\begin{abstract}
The study of values in folklore can be used as a medium to educate and teach. This study aims to explain the content of didactic values in the folklore of the origin of Boyolali Regency name. Through the analysis of the characters in the folklore of the origin of Boyolali Regency name, it was found the didactic values covering religious and social aspects. Meanwhile, the religious aspect is the value of didactic repentance and devout worship, while the social aspect is the value of didactic patience, sharing, hospitality, forgiveness, and admitting mistakes. This research was qualitative and used ethnographic strategies. Additionally, the data was obtained from observation, interviews, and analysis of documents. The didactic value content was obtained from the attitudes and behaviors of the figures Ki Ageng Pandanarang, Sunan Kalijaga, and the rogues.
\end{abstract}

Keywords: didactic value, folklore, the origin of the name of Boyolali Regency.

\section{INTRODUCTION}

$\mathrm{F}$ olklore is an oral tradition that is spread orally through generations (Vansina, 1958: 3). Beckwith (in Baker, 1992: 10) explains that folklore reflects culture, which is the embodiment of art that explores history in a particular culture. Folklore reflects the habits of society. In line with this, the development of folklore in a region is used as a guide to society's lives. Folklore contains values that can be used as guidance for people's lives. Bazimaziki et al. (2019), in their research, found that folklore can describe human life that can be used to convey important messages.

In applying the values or life arrangement, society often performs rigidly. For example, parents tend to give their children orders about things they should do and things that should be left, so a child feels that others too much organize his or her life. The rigid pattern of teaching indeed makes a child reluctant to apply these values in daily life. It takes subtle ways to teach the values of life; one of them is through folklore.

Folklore can be used as a medium to introduce the values of life and social arrangement. Harits (2017) states that folklore is used as a means of didacticism that can convey one community's values, such as social, historical, religious, and moral values. Through the introduction of folklore, a person can analyze the character of the character in the story. Furthermore, he/she can exemplify the characters in folklore to be applied in daily life.

\section{LITERATURE REVIEW}

Folklore

The folklore that appears in society becomes an identity that distinguishes people from each other (Ziolkowski, 1956: 31). Anderson (2006: 2) states that folklore becomes part of a culture of the society that is preserved consciously or unconsciously. Vansina (1985: 3) states that folklore as an oral tradition undergoes the process of spreading from previous generations to next generations by word of mouth. Furthermore, McNeill (2013: 16) explains that folklore is an informal and traditional culture of culturecustoms, stories, jokes, art-that is learned from each other and transmitted by word of mouth. Regarding these opinions, it can be synthesized that folklore is one of the cultural products that develop in society through generations and is transmitted orally.

As an oral tradition, folklore is known by the society for its entertainment purposes, containing events that occur unusually in everyday life (fantastic or magical), distinguished by the structure of particular compositions and styles (Nikiforov in Propp, 2012: 16). Huck \&Kiefer (2010: 227) argue that folklore is literature derived from the human imagination to explain the human condition. Dundes (2007: 1) explains that folklore is an artistic process of relics in the form of artifacts in the form of words that live dynamically in society and are loaded with values to serve as a guide to life. These values are often strong moral lessons-cherished goodness, greed, legal selfishness (Hoffman, 2018: 5).

The division of folklore types is also presented by Sherman (2008: xx), namely in the form of folklore, some children rhymes and some nonsense rhymes, myths, religious stories, epics, ballads, fairy tales, and legends. Bascom (2018: 9) classifies folklore into three types: fairy tales, legends, and myth. Fairy tales are folk prose that is not considered actually to happen by the story owner, and the fairy tale is not bound by time or place. Legend is folk prose that is considered to have actually happened, but it is not considered sacred. Besides, myth is a folk prose story that tells the story of gods or beings considered demigods and considered sacred by society.

\section{Didactic Values}

Ruys (2008: 43) says that didactic derives from the Greek word for teaching. Daniela (2019: 82) states that 
didactic is a theory to investigate the values of education with the aim to develop human physical, mental, and social. Following it, Bergman (2014: 32) defines didactic as the ability to show certain learning content so that someone does something with complete awareness. Based on some of these opinions can be synthesized that didactic is a charge of value that can be used to educate a person.

Beauvais (2015: 41) reveals that the content of didactic value contained in literary works becomes a medium for developing knowledge because one is invited to take a mandate in the past to apply for the future. Furthermore, Rainsford (2014: 154) reveals that didactic content and moral value are good literary traits. Emphasizing previous ideas, Shirane (2002: 450) conveys that the value of didactic and moral lessons is what is offered in literary writing. Based on some of these descriptions, it can be synthesized that didactic value becomes the core of literary creation.

\section{METHODS}

This research is a qualitative type with an ethnographic strategy. Spradley (1979: 5) states that ethnographic research can be used to determine the culture that develops in society. The research was conducted in Selo District, Boyolali Regency for two months, namely December 2020 to January 2021. Researchers collected data in three ways, namely observation, interviews, and literature study. Data were collected according to research cycle procedures, in the form of selecting ethnographic projects, asking ethnographic questions, collecting ethnographic data, making ethnographic notes, analyzing ethnographic data, and writing ethnographies. Researchers chose Selo District, Boyolali Regency because there are many local wisdoms and folklore that develop in the community. Informants are selected based on the recommendations of local residents, namely a community leader and cultural actor in the area. The researcher asked questions related to the folklore that developed in the area, then the researcher collected ethnographic data with in-depth interviews and focused on the folklore of the name Boyolali City. The researcher took notes and recorded during the observation. After all the data were collected, the researcher triangulated. Creswelll (2009: 219) argues that triangulation is done to ensure the correctness of the data. The next stage is data analysis and ethnographic research writing. The analysis was performed using the Miles and Huberman flow model.

\section{RESULT AND DISCUSSION}

The origin of Boyolali regency name is one of the folklores that developed in the Boyolali Regency. This story tells the story of Ki Ageng Pandanarang, a Regent of Semarang, who is very rich. His wealth made him love the world and forget worship. At that time, Sunan Kalijaga was sent to revive Ki Ageng Pandanarang. Sunan Kalijaga had an interesting namely by disguising. The first being in disguise, Sunan Kalijaga disguised himself as a grass seller, and the second he disguised himself as someone in beautiful clothes.
The two disguises did not succeed in making Ki Ageng Pandanarang realized his actions.

The third being in disguise, Sunan Kalijaga disguised himself as a beggar. When Ki Ageng Pandanarang gave the beggar money, the beggar said that all he needed was not money but to re-recite the adhan in the mosque. The beggar also advised Ki Ageng Pandanarang so that he would return to worship. Being offended, Ki Ageng Pandanarang scolded the beggar, but the beggar finally showed his power by hoeing the ground that turned to gold. The incident eventually made Ki Ageng Pandanarang realized. He also wanted to repent and travel with his wife, Nyi Ageng Kaliwungu, to tembayat. On their way, they met two rogues. However, finally, the rogues realized and became followers of Ki Ageng Pandanarang.

In the middle of the journey, Ki Ageng Pandanarang prayed by the river. At that time, Nyi Ageng Kaliwungu was left behind and far behind. He also said, "Boya wis lali teka Kyai ninggal aku," which means whether Ki Ageng Pandanarang had forgotten, so he left her. The phrase is used to name the stopover place of Ki Ageng Pandanarang and Nyi Ageng Kaliwungu, which is currently known as Boyolali.

Based on the description of folklore findings above, it can be known that the origin of the name Boyolali comes from the story of Ki Pandanarang. This story contains much good didactic value to imitating. Here are the didactic values found in the folklore of the origin of Boyolali Regency name.

Table 1 Analysis of the didactic values in the folklore of the origin of Boyolali Regency Name

\begin{tabular}{|c|c|c|}
\hline Aspects & Didactic Values & Description \\
\hline \multirow[t]{2}{*}{ Religious } & Repentance & $\begin{array}{l}\text { Ki Ageng Pandanarang no } \\
\text { longer thought about his } \\
\text { treasure and wealth but } \\
\text { wanted to learn to deepen } \\
\text { his religious knowledge in } \\
\text { order to focus on worship. }\end{array}$ \\
\hline & $\begin{array}{l}\text { Obedient to do } \\
\text { worship }\end{array}$ & $\begin{array}{l}\text { Ki Ageng Pandanarang } \\
\text { performed worship even on } \\
\text { the way and used scratch } \\
\text { equipment. }\end{array}$ \\
\hline \multirow{5}{*}{ Social } & Patience & $\begin{array}{l}\text { Sunan Kalijaga realized Ki } \\
\text { Ageng Pandanarang } \\
\text { smoothly and patiently. }\end{array}$ \\
\hline & Sharing & $\begin{array}{l}\text { Ki Ageng Pandanarang } \\
\text { gave money to beggars who } \\
\text { came to his palace. }\end{array}$ \\
\hline & Hospitality & $\begin{array}{l}\text { Ki Ageng Pandanarang } \\
\text { welcomed guests warmly } \\
\text { and kindly. }\end{array}$ \\
\hline & Forgiving & $\begin{array}{l}\text { Sunan Kalijaga forgave the } \\
\text { actions of Ki Ageng } \\
\text { Pandanarang. Similarly, Ki } \\
\text { Pandanarang forgave the } \\
\text { mistakes of the rogues he } \\
\text { encountered on the way. }\end{array}$ \\
\hline & $\begin{array}{l}\text { Admitting } \\
\text { mistakes }\end{array}$ & $\begin{array}{l}\text { It was done by Ki } \\
\text { Pandanarang, who wanted } \\
\text { to admit his mistake to } \\
\text { Sunan Kalijaga. It was also } \\
\text { done by two rogues who } \\
\text { admitted their fault to Ki } \\
\text { Ageng Pandanarang. }\end{array}$ \\
\hline
\end{tabular}


The table above explains that, in general, the folklore of the origin of the Boyolali Regency name has two types of didactic values, namely religious and social aspects. The religious aspect is shown by the attitude of $\mathrm{Ki}$ Ageng Pandanarang in the story. First, Ki Ageng Pandanarang repented to change himself for the better. He no longer thought of the treasure and wealth of the world. Furthermore, he intended to deepen the teachings of religion. Second, there is a didactic value in the form of obedience in worship. Wherever and under any circumstances, $\mathrm{Ki}$ Ageng Pandanarang did not leave prayers. It is found in the story when Ki Ageng Pandanarang prayed on a large rock by the river.

The folklore of the origin of the Boyolali Regency name contains didactic values related to social aspects, namely politeness, sharing, hospitality, forgiveness, and willingness to admit mistakes. The patience that is manifested by the behavior of Sunan Kalijaga in realizing Ki Ageng Pananarang was in various subtle ways. The next behavior is sharing that Ki Ageng Pandanarang embodied when giving money to beggars who came to his palace. It teaches society that in life, they have to share and help people who are deficient.

The next didactic value is hospitality, which $\mathrm{Ki}$ Ageng Pandanarang showed in welcoming and serving food for guests who came to his palace. He welcomed with hospitality and invited his guests to tour the palace. Ki Ageng Pandanarang's attitude teaches that the host should welcome guests well with hospitality and warmth.

Furthermore, folklore teaches to have a forgiving attitude. It is illustrated by the figure of Sunan Kalijaga, who easily apologized to Ki Ageng Pandanarang for his behavior. Besides, the forgiving nature is also depicted in the character $\mathrm{Ki}$ Ageng Pandanarang who was willing to forgive the rogues' actions who confronted him on the way. Besides being a forgiving person, this folklore teaches people to dare to admit their mistakes and change into better persons. It is illustrated by Ki Pandanarang, who wanted to admit his mistakes to Sunan Kalijaga. The same thing was done by two rogues who apologized to Ki Pandanarang and his wife.

Based on the description above, it can be synthesized that the research findings align with Bascom's theory (2018: 9) on classifying folklore. The origin of Boyolali Regency name is a legend because it tells the events of a location. Furthermore, the folklore contains didactic values that can be used to be taught to the community. The findings of these didactic values are in line with Daniela's opinion (2019: 82), stating that didactic is a theory to investigate the values of education with the aim of physical, mental, and social development of humans.

\section{CONSLUSION}

The folklore of the origin of Boyolali Regency name contains good didactic values taught to the society. The didactic value is in the form of religious and social aspects. Religious aspects include the didactic value of repentance and the worship system, while the social aspects are patience, sharing, hospitality, forgiveness, and admitting mistakes. These values are derived from the attitudes and behaviors of ki Ageng Pandanarang, Sunan Kalijaga, and rogues.

\section{ACKNOWLEDGMENT}

The authors received funding from LPDP for this

work.

\section{REFERENCES}

[1]. Anderson, G. (2006). Greek and Roman Folklore: A Handbook. United States of America: Greenwood Publishing Group, Inc.

[2]. Baker, R. L. (1992). The Folklore Historian. United State: Indiana State University.

[3]. Bascom, W. R. (1965). Four Function of Folklor. Englewood Cliff: NJ. Prentice Hall, Inc.

[4]. Bazimaziki, G., Bisamaza, E., Ndayishimiye, J. L., \& Nsabumuremyi, L. (2019). The Socio-didactic Function of Oral Literary Genres: A Paremiological Perspectivism of Selected Ethical Proverbs. International Journal of Linguistics, Literature and Translation (IJLLT), 2(2), 20-27. https://doi.org/10.32996/ijllt.2019.2.2.3

[5]. Beauvais, Clémentine. (2015). He Mighty Child: Time and power in children's literature. United State of America: John Benjamins B.V.

[6]. Bergman, L. dkk. (2014). EDUCARE 2014:4 Childhood, Learning and Didactics. Holmbergs: Malmö Hogskola.

[7]. Creswell, J. W. (2009). Research Design: Qualitative, Quantitative, and Mixed Methods Approaches. United States of America: Sage Publication, Inc.

[8]. Daniela, L. (2019). Didactics of Smart Pedagogy. Switzerland: Springer.

[9]. Dundes, A. (2007). The Meaning of Folklore: The Analytical Essays of Alan Dundes. Logan: Utag State University Press.

[10]. Harits, I. W. (2017). Comparative Children Literature: Aesthetic and Didactic Context. E-Pedagogium, 17(2), 15-24. https://doi.org/10.5507/epd.2017.021

[11]. Huck \& Kiefer. (2010). Charlotte Huck's Children Literature. New York: Mc Graw Hill.

[12]. Hoffman, M. (2018). A First Book of Fairy Tales. United States: DK Publishing.

[13]. McNeill, L. S. (2013). Folklore Rules. United States of America: University Press of Colorado.

[14]. Propp. (2012). The Russian folktale by Vladimir Yakovlevich Propp. United States of America: Wayne State University Press.

[15]. Rainsford, D. (2014). Studying Literature in English an introduction. New York: Routledge.

[16]. Ruys, J. F. (2008). WHAT NATURE DOES NOT TEACH: Didactic Literature in the Medieval and Early-Modern Periods. Belgium: Brepols.

[17]. Sherman, J. (2008). Storytelling. New York: Sharpe Reference.

[18]. Shirane, H. (2002). Early Modern Japanese Literature. New York: Columbia University Press.

[19]. Spradley, J. P. (1979). The Ethnograhic Interview. United States of America: Harcourt Brace Jovanovich College Publishers.

[20]. Vansina, J. (1985). Oral Tradition as History. United States of America: The University of Wisconsin Press.

[21]. Ziolkowski, J. M. (1956). Fairy Tales from Before Fairy Tales: The Medieval Latin Past of Wonderful Lies. United States: The University of Michigan Press. 